\title{
Hematopoietic stem cell aging and chronic lymphocytic leukemia pathogenesis
}

\author{
Yoshikane Kikushige $\cdot$ Toshihiro Miyamoto
}

Received: 18 April 2014/Revised: 22 July 2014/Accepted: 22 July 2014/Published online: 7 August 2014

(C) The Japanese Society of Hematology 2014

\begin{abstract}
Human malignancies develop through the multistep acquisition of critical somatic mutations during the clinical course. Regarding hematological malignancies, recent novel findings have indicated that hematopoietic stem cells (HSCs), which have the potential to self-renew and differentiate into multilineage hematopoietic cells, are an important cellular target for the accumulation of critical somatic mutations and play a central role in myeloid malignancy development. In contrast to myeloid malignancies, mature lymphoid malignancies, such as chronic lymphocytic leukemia (CLL), are considered to directly originate from differentiated mature lymphocytes; however, we previously reported that the propensity to generate clonal B cells had already been acquired at the HSC stage in CLL patients. Similarly, HSC involvement has been reported in the pathogenesis of mature $\mathrm{T}$ cell lymphomas. These studies indicate that, in mature lymphoid, if not all, malignancies, HSCs should be considered as the critical cellular target in the oncogenic process. The prevalence of these hematological malignancies dramatically increases with age, and the effect of aging HSCs should thus be taken into account when investigating the stepwise malignant transformation process of these age-associated malignancies.
\end{abstract}

Keywords Hematopoietic stem cell - Chronic lymphocytic leukemia $\cdot$ Stem cell aging

Y. Kikushige · T. Miyamoto $(\square)$

Department of Medicine and Biosystemic Sciences, Kyushu

University Graduate School of Medicine, 3-1-1 Maidashi,

Higashi-Ku, Fukuoka 812-8582, Japan

e-mail: toshmiya@intmed1.med.kyushu-u.ac.jp

Y. Kikushige

Japan Society for the Promotion of Science, Tokyo, Japan

\section{Introduction}

Malignant transformation can occur through a multistep process of acquiring critical somatic mutations. Therefore, to accumulate such mutations, malignant stem cells should have a long life span. Accordingly, in human hematopoiesis, genetic abnormalities associated with malignant transformation should be accumulated in self-renewing HSCs. HSCs have a very long life span, thus allowing these cells to maintain all types of hematopoietic cells throughout the human life span. In addition to a very long life span, HSCs have the potential for self-renewal and differentiation into mature blood cells as the central function of tissue stem cells. These properties enable HSCs to propagate both self-renewing HSCs and hematopoietic progenies that carry identical genetic abnormalities [1]. Therefore, HSCs represent the ideal cellular target for early oncogenic events that occur during the stepwise malignant transformation of hematopoietic malignancies.

Recent advances in next-generation sequencing (NGS) techniques have made it possible to identify recurrent somatic mutations and the clonal evolution process in many hematological malignancies [2-8]. These technologies have also succeeded in demonstrating that somatic mutations could be accumulated within HSCs, and that in humans, the number of acquired somatic mutations in HSCs or progenitor cells increases with age [9]. We previously reported the existence of premalignant HSCs that carried the $[8,21]$ translocation and could contribute to normal hematopoiesis in acute myelogenous leukemia (AML) [10]. Furthermore, NGS enabled the identification of premalignant clones carrying somatic mutations in phenotypically normal HSC populations in patients with various types of AML without specific chromosomal abnormalities [11, 12]. Therefore, self-renewing HSCs are 
now considered to be the origin of several hematological malignancies, particularly in myeloid malignancies [13]. In contrast, reports of HSC involvement in disease progression are not common with respect to mature lymphoid malignancies because these malignancies are considered to arise directly from mature differentiated lymphocytes. Recently, we and another group reported that even in these mature lymphoid malignancies, which include CLL [14] and $\mathrm{T}$ cell lymphoma [15], the patients' HSCs were primarily involved in the pathogenesis of malignant transformation during multistep disease progression.

Unlike normal HSCs, HSCs from CLL patients gave rise to monoclonal or oligoclonal mature $\mathrm{B}$ cells that simulated monoclonal B cell lymphocytosis (MBL), the preleukemic state of CLL, after xenogeneic transplantation. These results indicated that in CLL, HSCs possess the cellintrinsic propensity to generate clonal CLL-like B cells [14]. CLL is the most common hematological malignancy among elderly individuals in Western countries [16, 17], and the prevalence of CLL and MBL has also dramatically increased with age [18, 19]. Aging induces functional changes in the human hematopoietic system, including self-renewing HSCs. Therefore, when investigating HSC involvement in CLL pathogenesis, the relationship between HSCs aging and leukemogenesis should be discussed. In this review, we will focus on the effects of aging on HSCs and their involvement in CLL pathogenesis.

\section{Aging of the hematopoietic system}

Similar to the majority of organs and tissues, aging affects the human hematopoietic system [20], and this is associated with an increased incidence of myeloid malignancies [21], anemia [22], and immune dysfunction [23]. Among hematopoietic cells, HSCs have been intensively investigated as a cellular target for aging. HSC aging is accompanied by several biological changes such as the accumulation of genomic damage [24], epigenetic changes [25], telomere shortening [26], and oxidative stress [27, 28]. These factors ultimately induce functional HSC deterioration. In mice, aged $\mathrm{HSCs}$ are characterized by an increased HSC pool size comprising cells with a predominantly myeloid-biased differentiation potential and reduced self-renewal activity [29-32]. The myeloid-biased HSC differentiation properties play a significant role in lymphoid senescence with aging; therefore, in mice, the myeloid skewing of aged HSCs was shown to result in the reduced production of both lymphoid progenitor cells and total B cells [30, 33-36].

These changes in aged HSCs are considered primarily cell intrinsic. However, HSCs reside in a bone marrow niche that comprises a specific cellular component and extracellular matrix proteins. The bone marrow provides this environment for HSCs, and the balance between selfrenewal and differentiation is controlled by a combination of cell-intrinsic and external regulatory machineries, including this niche $[37,38]$. These bone marrow microenvironments, including the HSC niche, are believed to be affected by aging. The precise machineries regarding how the aging process affects the interaction between HSCs and their microenvironment are largely unknown; however, reduced bone formation and the accumulation of fat are evident with age. These age-related changes in the bone and bone marrow induce changes in the interactions between HSCs and their niche. For example, in mice, the aging bone marrow microenvironment affects rag2 expression, resulting in an age-related reduction of pre-B cells [34]. In addition to the effects on normal hematopoiesis, recent studies have demonstrated that the genetically modified bone marrow environment, including osteoblasts that are the critical components of the HSC niche, can induce a pre-AML state and AML in mouse models [39-41]. These findings suggested that the aging microenvironment may affect the pathogenesis of human hematological malignancies via external stimulation, regardless of the cell-intrinsic malignant transformation process.

Similar to murine hematopoiesis, recent human studies that used precise immune phenotypical analyzes and improved xenograft models revealed that relative to young HSCs, aged phenotypic $\mathrm{CD} 34^{+} \mathrm{CD} 38^{-} \mathrm{CD} 90^{+} \mathrm{CD} 45 \mathrm{RA}^{-}$ $\mathrm{Lin}^{-}$HSCs increased in frequency and exhibited a myeloidbiased differentiation potential [42], and that $\mathrm{CD} 34^{+-}$ $\mathrm{CD} 38^{-} \mathrm{CD} 90^{-} \mathrm{CD} 45 \mathrm{RA}^{+} \mathrm{CD} 10^{+}$early B cells and $\mathrm{CD} 34^{+-}$ $\mathrm{CD} 19^{+}$pro-B cells decreased with age [43]. In clinic settings, age-related functional changes in human HSCs are particularly important with respect to HSC transplantation (HSCT) [44-46]. HSCT from either related or unrelated donors provides an important therapeutic strategy for treating both malignant and nonmalignant hematologic diseases. Regarding allogeneic HSCT, large retrospective analysis of the National Marrow Donor Program (NMDP) registry reported that advanced donor age was the only factor significantly associated with overall reduced disease-free survival of the HSCT recipients [47], whereas NMDP data analysis that incorporated high-resolution donor-recipient human leukocyte antigen (HLA) matching did not find a significant association between the donor age and patient survival [48]. Therefore, the significance of HSC aging in allogeneic HSCT remains controversial. In addition to HSCT donor source challenges, age-related functional HSC changes are also important to understanding the pathogenesis of hematological malignancies.

Generally, the myeloid-biased differentiation potential of HSCs is believed to be associated with the increased 
incidence of myeloid malignancies in elderly individuals. Furthermore, the lower incidence of acute lymphoblastic leukemia, a very immature lymphoid malignancy, in elderly individuals relative to young individuals could be considered a consequence of impaired lymphopoiesis in the elderly. However, CLL is the most prevalent hematological malignancy among elderly individuals in Western countries, and the prevalence of other mature lymphoid malignancies also increases with age. In this context, it is conceivable that in humans, HSC aging may affect the pathogenesis of both mature lymphoid and myeloid malignancies. Many myeloid malignancies such as AML, chronic myeloid leukemia, and myelodysplastic syndromes arise from HSCs or very immature hematopoietic progenitors, whereas mature lymphoid malignancies are generally believed to arise directly from mature lymphoid cells. Importantly, these mature lymphoid cells, which are the origins of mature lymphoid malignancies, are also the progeny of HSCs. Therefore, when we consider the pathogenesis of mature lymphoid malignancies, particularly in elderly individuals, the effects of HSC aging should be taken into account in some, if not all, mature lymphoid malignancies. Accordingly, we have focused on CLL, the most prevalent lymphoid malignancy in elderly individuals and investigated the involvement of aged HSCs in CLL pathogenesis.

\section{CLL pathogenesis}

Chronic lymphocytic leukemia (CLL), the most common form of leukemia among adults in Western countries, is a mature $\mathrm{B}$ cell malignancy characterized by the accumulation of clonal mature B cells in the blood, bone marrow, and lymphoid tissues [16, 17]. The consistent clonal expansion of mature frequently CD5-expressing B cells represents the major CLL patient phenotype. The prevalence of CLL increases dramatically with age. Human CLL cells express functional B cell receptors (BCRs) on their cell surfaces as a result of productive immunoglobulin gene rearrangement $[16,49,50]$. CLL cases can be divided into two subgroups based on the presence of somatic hypermutations within the variable regions of the immunoglobulin heavy chain (IGH) genes; these mutations occur in the germinal centers during the naïve-to-memory B cell transition in the normal B cell development process. CLL patients with mutated BCRs have a more favorable prognosis than those with unmutated BCRs [51]. It has been postulated that both types of CLL originate from selfreactive $\mathrm{B}$ cell precursors, and that the $\mathrm{BCR}$ somatic hypermutation status does not indicate the origin of CLL cells [52-54]. However, recent CLL transcriptome analysis indicated that unmutated CLL is derived from unmutated mature $\mathrm{CD}^{+} \mathrm{B}$ cells, whereas mutated CLL is derived from a $\mathrm{CD} 5^{+} \mathrm{CD} 27^{+}$postgerminal center $\mathrm{B}$ cell subset [55]. The cellular origin of CLL remains controversial, and further studies will be needed to clarify the multistep leukemogenic process of CLL. Regarding the role of the BCR in CLL pathogenesis, it is important to note that among CLL cells, approximately $1 \%$ of cells from both groups express nearly identical BCRs, and the BCRs of CLL cells can be classified as specific stereotyped BCRs in approximately $30 \%$ of CLL cases, suggesting that these BCR similarities should result from antigen selection during CLL progression [56-58]. However, a recent study revealed that CLL-derived BCRs induced antigen-independent cell-autonomous signaling in CLL cells, thus providing new insight into the BCR-related pathogenesis of CLL [59].

\section{HSC involvement in CLL pathogenesis}

To trace the origins of genetic aberrations in human CLL, it is important to note that CLL is not always a monoclonal disorder. Multiple CLL clones were reportedly found in $3.4 \%$ of typical CLL patients and $13.8 \%$ of atypical CLL patients [60]. Furthermore, a large cohort study demonstrated that 44 of 45 CLL patients exhibited a precursor state such as MBL for 6 months-7 years [19]; therefore, virtually all CLL cases are likely preceded by MBL. MBL is considered an essential preleukemic state of CLL representing the asymptomatic proliferation of clonal B cells with circulating numbers $<5,000 / \mu 1$ [61]. The prevalence of MBL is known to increase with age $[18,19]$. The reported MBL prevalence ranges from $<1 \%[62,63]$ to $18 \%$ [64], depending on the evaluated populations and the detection methods. Most MBL clones exhibit an immunophenotype similar to that of CLL [65], and CLL requiring treatment develops in subjects with CLL-like phenotypes and lymphocytosis at an annual rate of $1.1-1.4 \%[18,66]$. Of note, human MBL sometimes comprises multiple B cell clones [67-70].

If progression from MBL to CLL reflects stepwise leukemogenesis, the stage at which the first oncogenic event occurs remains unknown. The existence of oligoclonal B cell clones in both CLL and MBL patients strongly suggests that the first oncogenic event may be traced as far back as the progenitor or self-renewing HSC with germline IGH genes. These observations led us to evaluate the very primitive HSC fraction in CLL patients. We used xenograft models to investigate HSCs from CLL patients in vivo. In our analysis, CLL cells were never directly engrafted; however, self-renewing $\mathrm{CD} 34^{+} \mathrm{CD} 38^{-}$HSC populations from CLL patients were engrafted for long periods and differentiated into cells from multiple hematopoietic 
(MBL)

(CLL)

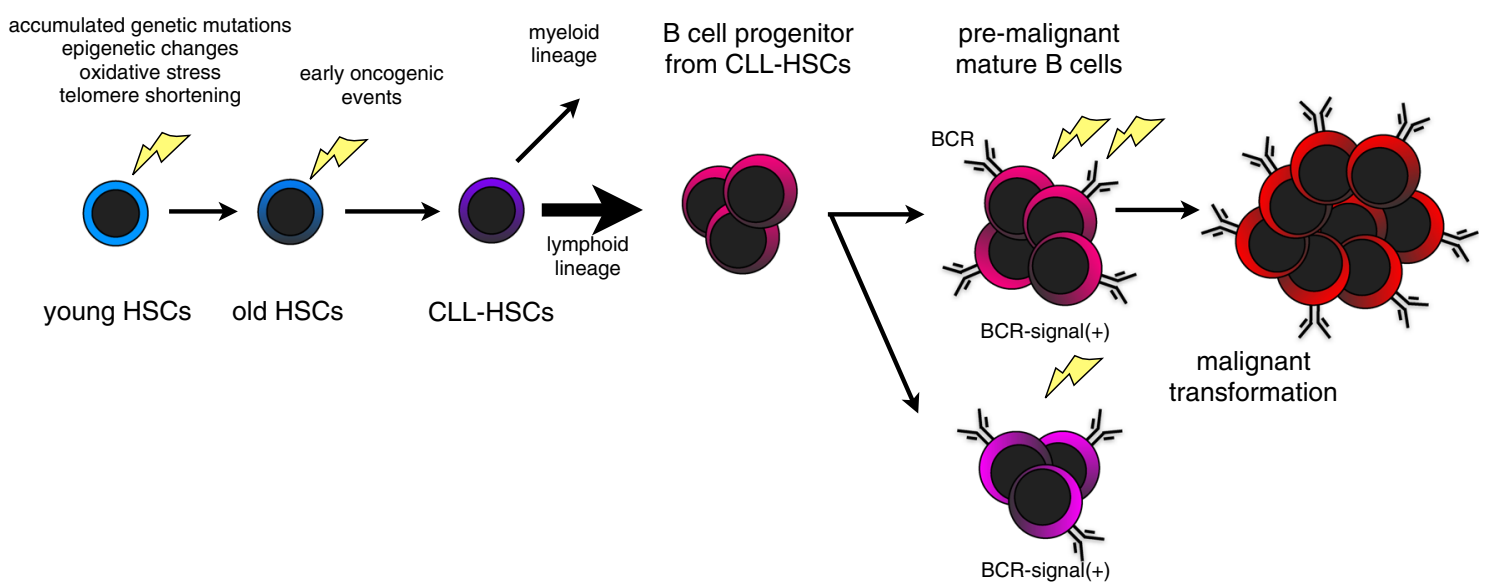

Fig. 1 Schematic presentation of human chronic lymphocytic leukemia (CLL) development from hematopoietic stem cells (HSCs) CLLHSCs carry accumulated genetic abnormalities that may influence skewed $\mathrm{B}$ cell differentiation, leading to the production of a high number of polyclonal B cells that carry the same genetic aberrations.

lineages, including the myeloid and lymphoid lineages, in the immunodeficient mice. We found that HSCs derived from CLL patients (CLL-HSCs) gave rise to a mature B cell compartment that contained monoclonal or oligoclonal $\mathrm{B}$ cells that were independent of their original CLL clones, thus recapitulating human CLL or MBL-like phenotypes in mice. Single-cell gene expression analysis revealed that these CLL-HSCs expressed a skewed lymphoid gene expression signature relative to that of normal adult HSCs. These findings strongly suggested that the propensity to generate clonal B cells has already been acquired at the HSC stage [14]. Our hypothesis regarding CLL development has been schematized in Fig. 1. Consistent with our findings in CLL patients, TET2 mutations were identified in both the myeloid and lymphoid cells of some patients with mature T cell lymphoma, again suggesting HSC involvement in the pathogenesis of some mature lymphoid malignancies [15]. These studies have suggested that selfrenewing HSCs may be a common target for oncogenic events in human hematological malignancies, including both mature lymphoid malignancies and myeloid neoplasms.

\section{Conclusion}

Recent studies have indicated HSC involvement in the pathogenesis of mature lymphoid malignancies in addition to myeloid neoplasms. These findings can be explained on
These B cell clones are selected and expanded in response to B cell receptor signaling. The further accumulation of leukemogenic events should be necessary for the full transformation of monoclonal B cell lymphocytic clones to clinical CLL

consideration of the multistep pathogenesis of human agerelated hematological neoplasms. Notably, these data do not indicate that the tumor-initiating cells exist within the HSC compartment but rather that a priming process that enables the emergence or propagation of premalignant clones may be initiated within self-renewing HSCs during the pathogenesis of hematological malignancies. Further studies will clarify the precise molecular mechanisms through which the primed or aged HSCs play a central role in the stepwise malignant transformation process.

\section{References}

1. Rossi DJ, Jamieson CH, Weissman IL. Stems cells and the pathways to aging and cancer. Cell. 2008;132(4):681-96.

2. Ding L, Ley TJ, Larson DE, Miller CA, Koboldt DC, Welch JS, et al. Clonal evolution in relapsed acute myeloid leukaemia revealed by whole-genome sequencing. Nature. 2012;481(7382):506-10.

3. Walter MJ, Shen D, Ding L, Shao J, Koboldt DC, Chen K, et al. Clonal architecture of secondary acute myeloid leukemia. N Engl J Med. 2012;366(12):1090-8.

4. Yoshida K, Sanada M, Shiraishi Y, Nowak D, Nagata Y, Yamamoto R, et al. Frequent pathway mutations of splicing machinery in myelodysplasia. Nature. 2011;478(7367):64-9.

5. Wang L, Lawrence MS, Wan Y, Stojanov P, Sougnez C, Stevenson $\mathrm{K}$, et al. SF3B1 and other novel cancer genes in chronic lymphocytic leukemia. N Engl J Med. 2011;365(26):2497-506.

6. Puente XS, Pinyol M, Quesada V, Conde L, Ordonez GR, Villamor $\mathrm{N}$, et al. Whole-genome sequencing identifies recurrent 
mutations in chronic lymphocytic leukaemia. Nature. 2011;475(7354):101-5.

7. Quesada V, Conde L, Villamor N, Ordonez GR, Jares P, Bassaganyas $\mathrm{L}$, et al. Exome sequencing identifies recurrent mutations of the splicing factor SF3B1 gene in chronic lymphocytic leukemia. Nat Genet. 2012;44(1):47-52.

8. Sakata-Yanagimoto M, Enami T, Yoshida K, Shiraishi Y, Ishii R, Miyake $\mathrm{Y}$, et al. Somatic RHOA mutation in angioimmunoblastic T cell lymphoma. Nat Genet. 2014;46(2):171-5.

9. Welch JS, Ley TJ, Link DC, Miller CA, Larson DE, Koboldt DC, et al. The origin and evolution of mutations in acute myeloid leukemia. Cell. 2012;150(2):264-78.

10. Miyamoto T, Weissman IL, Akashi K. AML1/ETO-expressing nonleukemic stem cells in acute myelogenous leukemia with 8;21 chromosomal translocation. Proc Natl Acad Sci USA. 2000;97(13):7521-6.

11. Jan M, Snyder TM, Corces-Zimmerman MR, Vyas P, Weissman IL, Quake SR, et al. Clonal evolution of preleukemic hematopoietic stem cells precedes human acute myeloid leukemia. Sci Transl Med. 2012;4(149):149ra18.

12. Shlush LI, Zandi S, Mitchell A, Chen WC, Brandwein JM, Gupta $\mathrm{V}$, et al. Identification of pre-leukaemic haematopoietic stem cells in acute leukaemia. Nature. 2014;506(7488):328-33.

13. Walter MJ, Ding L, Shen D, Shao J, Grillot M, McLellan M, et al. Recurrent DNMT3A mutations in patients with myelodysplastic syndromes. Leukemia. 2011;25(7):1153-8.

14. Kikushige Y, Ishikawa F, Miyamoto T, Shima T, Urata S, Yoshimoto G, et al. Self-renewing hematopoietic stem cell is the primary target in pathogenesis of human chronic lymphocytic leukemia. Cancer Cell. 2011;20(2):246-59.

15. Quivoron C, Couronne L, Della Valle V, Lopez CK, Plo I, Wagner-Ballon $\mathrm{O}$, et al. TET2 inactivation results in pleiotropic hematopoietic abnormalities in mouse and is a recurrent event during human lymphomagenesis. Cancer Cell. 2011;20(1):25-38.

16. Chiorazzi N, Rai KR, Ferrarini M. Chronic lymphocytic leukemia. N Engl J Med. 2005;352(8):804-15.

17. Zenz T, Mertens D, Kuppers R, Dohner H, Stilgenbauer S. From pathogenesis to treatment of chronic lymphocytic leukaemia. Nat Rev Cancer. 2011;10(1):37-50.

18. Rawstron AC, Bennett FL, O'Connor SJ, Kwok M, Fenton JA, Plummer M, et al. Monoclonal B-cell lymphocytosis and chronic lymphocytic leukemia. N Engl J Med. 2008;359(6):575-83.

19. Landgren O, Albitar M, Ma W, Abbasi F, Hayes RB, Ghia P, et al. B-cell clones as early markers for chronic lymphocytic leukemia. N Engl J Med. 2009;360(7):659-67.

20. Snoeck HW. Aging of the hematopoietic system. Curr Opin Hematol. 2013;20(4):355-61.

21. Lichtman MA, Rowe JM. The relationship of patient age to the pathobiology of the clonal myeloid diseases. Semin Oncol. 2004;31(2):185-97.

22. Beghe C, Wilson A, Ershler WB. Prevalence and outcomes of anemia in geriatrics: a systematic review of the literature. Am $\mathrm{J}$ Med. 2004;5(116 Suppl 7A):3S-10S.

23. Linton PJ, Dorshkind K. Age-related changes in lymphocyte development and function. Nat Immunol. 2004;5(2):133-9.

24. Nijnik A, Woodbine L, Marchetti C, Dawson S, Lambe T, Liu C, et al. DNA repair is limiting for haematopoietic stem cells during ageing. Nature. 2007;447(7145):686-90.

25. Beerman I, Bock C, Garrison BS, Smith ZD, Gu H, Meissner A, et al. Proliferation-dependent alterations of the DNA methylation landscape underlie hematopoietic stem cell aging. Cell Stem Cell. 2013;12(4):413-25.

26. Sahin E, Depinho RA. Linking functional decline of telomeres, mitochondria and stem cells during ageing. Nature. 2010;464(7288):520-8.
27. Yahata T, Takanashi T, Muguruma Y, Ibrahim AA, Matsuzawa $\mathrm{H}$, Uno $\mathrm{T}$, et al. Accumulation of oxidative DNA damage restricts the self-renewal capacity of human hematopoietic stem cells. Blood. 2011;118(11):2941-50.

28. Mantel C, Messina-Graham S, Moh A, Cooper S, Hangoc G, Fu $\mathrm{XY}$, et al. Mouse hematopoietic cell-targeted STAT3 deletion: stem/progenitor cell defects, mitochondrial dysfunction, ROS overproduction, and a rapid aging-like phenotype. Blood. 2012;120(13):2589-99.

29. Sudo K, Ema H, Morita Y, Nakauchi H. Age-associated characteristics of murine hematopoietic stem cells. J Exp Med. 2000;192(9):1273-80.

30. Rossi DJ, Bryder D, Zahn JM, Ahlenius H, Sonu R, Wagers AJ, et al. Cell intrinsic alterations underlie hematopoietic stem cell aging. Proc Natl Acad Sci USA. 2005;102(26):9194-9.

31. Morrison SJ, Wandycz AM, Akashi K, Globerson A, Weissman IL. The aging of hematopoietic stem cells. Nat Med. 1996;2(9):1011-6.

32. Dykstra B, Olthof S, Schreuder J, Ritsema M, de Haan G. Clonal analysis reveals multiple functional defects of aged murine hematopoietic stem cells. J Exp Med. 2011;208(13):2691-703.

33. Miller JP, Allman D. The decline in B lymphopoiesis in aged mice reflects loss of very early B-lineage precursors. J Immunol. 2003;171(5):2326-30.

34. Labrie JE 3rd, Sah AP, Allman DM, Cancro MP, Gerstein RM. Bone marrow microenvironmental changes underlie reduced RAG-mediated recombination and $\mathrm{B}$ cell generation in aged mice. J Exp Med. 2004;200(4):411-23.

35. Chinn IK, Blackburn CC, Manley NR, Sempowski GD. Changes in primary lymphoid organs with aging. Semin Immunol. 2012;24(5):309-20.

36. Min H, Montecino-Rodriguez E, Dorshkind K. Effects of aging on the common lymphoid progenitor to pro-B cell transition. J Immunol. 2006;176(2):1007-12.

37. Suda T, Arai F, Hirao A. Hematopoietic stem cells and their niche. Trends Immunol. 2005;26(8):426-33.

38. Arai F, Hirao A, Suda T. Regulation of hematopoiesis and its interaction with stem cell niches. Int $\mathrm{J}$ Hematol. 2005;82(5):371-6.

39. Walkley CR, Olsen GH, Dworkin S, Fabb SA, Swann J, McArthur GA, et al. A microenvironment-induced myeloproliferative syndrome caused by retinoic acid receptor gamma deficiency. Cell. 2007;129(6):1097-110.

40. Raaijmakers MH, Mukherjee S, Guo S, Zhang S, Kobayashi T, Schoonmaker JA, et al. Bone progenitor dysfunction induces myelodysplasia and secondary leukaemia. Nature. 2010;464(7290):852-7.

41. Kode A, Manavalan JS, Mosialou I, Bhagat G, Rathinam CV, Luo $\mathrm{N}$, et al. Leukaemogenesis induced by an activating betacatenin mutation in osteoblasts. Nature. 2014;506(7487):240-4.

42. Pang WW, Price EA, Sahoo D, Beerman I, Maloney WJ, Rossi DJ, et al. Human bone marrow hematopoietic stem cells are increased in frequency and myeloid-biased with age. Proc Natl Acad Sci USA. 2011;108(50):20012-7.

43. Kuranda K, Vargaftig J, de la Rochere P, Dosquet C, Charron D, Bardin F, et al. Age-related changes in human hematopoietic stem/progenitor cells. Aging Cell. 2011;10(3):542-6.

44. Artz AS. From biology to clinical practice: aging and hematopoietic cell transplantation. Biol Blood Marrow Trans J Am Soc Blood Marrow Transpl. 2012;18(1 Suppl):S40-5.

45. Van Zant G, Liang Y. Concise review: hematopoietic stem cell aging, life span, and transplantation. Stem Cells Trans Med. 2012;1(9):651-7.

46. Shima T, Miyamoto T, Kikushige Y, Mori Y, Kamezaki K, Takase K, et al. Quantitation of hematogones at the time of 
engraftment is a useful prognostic indicator in allogeneic hematopoietic stem cell transplantation. Blood. 2013;121(5):840-8.

47. Kollman C, Howe CW, Anasetti C, Antin JH, Davies SM, Filipovich $\mathrm{AH}$, et al. Donor characteristics as risk factors in recipients after transplantation of bone marrow from unrelated donors: the effect of donor age. Blood. 2001;98(7):2043-51.

48. Lee SJ, Klein J, Haagenson M, Baxter-Lowe LA, Confer DL, Eapen M, et al. High-resolution donor-recipient HLA matching contributes to the success of unrelated donor marrow transplantation. Blood. 2007;110(13):4576-83.

49. Stevenson FK, Caligaris-Cappio F. Chronic lymphocytic leukemia: revelations from the B-cell receptor. Blood. 2004;103(12):4389-95.

50. Caligaris-Cappio F, Ghia P. Novel insights in chronic lymphocytic leukemia: are we getting closer to understanding the pathogenesis of the disease? J Clin Oncol. 2008;26(27):4497-503.

51. Hamblin TJ, Davis Z, Gardiner A, Oscier DG, Stevenson FK. Unmutated $\operatorname{Ig} \mathrm{V}(\mathrm{H})$ genes are associated with a more aggressive form of chronic lymphocytic leukemia. Blood. 1999;94(6): 1848-54.

52. Herve M, Xu K, Ng YS, Wardemann H, Albesiano E, Messmer BT, et al. Unmutated and mutated chronic lymphocytic leukemias derive from self-reactive B cell precursors despite expressing different antibody reactivity. J Clin Invest. 2005;115(6):1636-43.

53. Klein U, Tu Y, Stolovitzky GA, Mattioli M, Cattoretti G, Husson $\mathrm{H}$, et al. Gene expression profiling of B cell chronic lymphocytic leukemia reveals a homogeneous phenotype related to memory $\mathrm{B}$ cells. J Exp Med. 2001;194(11):1625-38.

54. Rosenwald A, Alizadeh AA, Widhopf G, Simon R, Davis RE, Yu $\mathrm{X}$, et al. Relation of gene expression phenotype to immunoglobulin mutation genotype in B cell chronic lymphocytic leukemia. J Exp Med. 2001;194(11):1639-47.

55. Seifert M, Sellmann L, Bloehdorn J, Wein F, Stilgenbauer S, Durig J, et al. Cellular origin and pathophysiology of chronic lymphocytic leukemia. J Exp Med. 2012;209(12):2183-98.

56. Widhopf GF 2nd, Rassenti LZ, Toy TL, Gribben JG, Wierda WG, Kipps TJ. Chronic lymphocytic leukemia B cells of more than $1 \%$ of patients express virtually identical immunoglobulins. Blood. 2004;104(8):2499-504.

57. Stamatopoulos K, Belessi C, Moreno C, Boudjograh M, Guida G, Smilevska T, et al. Over $20 \%$ of patients with chronic lymphocytic leukemia carry stereotyped receptors: pathogenetic implications and clinical correlations. Blood. 2007;109(1):259-70.

58. Messmer BT, Raphael BJ, Aerni SJ, Widhopf GF, Rassenti LZ, Gribben JG, et al. Computational identification of CDR3 sequence archetypes among immunoglobulin sequences in chronic lymphocytic leukemia. Leuk Res. 2009;33(3):368-76.

59. Duhren-von Minden M, Ubelhart R, Schneider D, Wossning T, Bach MP, Buchner M, et al. Chronic lymphocytic leukaemia is driven by antigen-independent cell-autonomous signalling. Nature. 2012;489(7415):309-12.

60. Sanchez ML, Almeida J, Gonzalez D, Gonzalez M, GarciaMarcos MA, Balanzategui A, et al. Incidence and clinicobiologic characteristics of leukemic B-cell chronic lymphoproliferative disorders with more than one B-cell clone. Blood. 2003;102(8):2994-3002.

61. Marti GE, Rawstron AC, Ghia P, Hillmen P, Houlston RS, Kay $\mathrm{N}$, et al. Diagnostic criteria for monoclonal B-cell lymphocytosis. Br J Haematol. 2005;130(3):325-32.

62. Shim YK, Vogt RF, Middleton D, Abbasi F, Slade B, Lee KY, et al. Prevalence and natural history of monoclonal and polyclonal B-cell lymphocytosis in a residential adult population. Cytometry B Clin Cytom. 2007;72(5):344-53.

63. Rachel JM, Zucker ML, Fox CM, Plapp FV, Menitove JE, Abbasi $\mathrm{F}$, et al. Monoclonal B-cell lymphocytosis in blood donors. Br J Haematol. 2007;139(5):832-6.

64. Marti GE, Carter P, Abbasi F, Washington GC, Jain N, Zenger $\mathrm{VE}$, et al. B-cell monoclonal lymphocytosis and B-cell abnormalities in the setting of familial B-cell chronic lymphocytic leukemia. Cytometry B Clin Cytom. 2003;52(1):1-12.

65. Marti G, Abbasi F, Raveche E, Rawstron AC, Ghia P, Aurran T, et al. Overview of monoclonal B-cell lymphocytosis. Br J Haematol. 2007;139(5):701-8.

66. Shanafelt TD, Kay NE, Rabe KG, Call TG, Zent CS, Maddocks $\mathrm{K}$, et al. Brief report: natural history of individuals with clinically recognized monoclonal B-cell lymphocytosis compared with patients with Rai 0 chronic lymphocytic leukemia. J Clin Oncol. 2009;27(24):3959-63.

67. Nieto WG, Almeida J, Romero A, Teodosio C, Lopez A, Henriques $\mathrm{AF}$, et al. Increased frequency (12\%) of circulating chronic lymphocytic leukemia-like B-cell clones in healthy subjects using a highly sensitive multicolor flow cytometry approach. Blood. 2009;114(1):33-7.

68. Dagklis A, Fazi C, Sala C, Cantarelli V, Scielzo C, Massacane R, et al. The immunoglobulin gene repertoire of low-count chronic lymphocytic leukemia (CLL)-like monoclonal B lymphocytosis is different from CLL: diagnostic implications for clinical monitoring. Blood. 2009;114(1):26-32.

69. Lanasa MC, Allgood SD, Volkheimer AD, Gockerman JP, Whitesides JF, Goodman BK, et al. Single-cell analysis reveals oligoclonality among 'low-count' monoclonal B-cell lymphocytosis. Leukemia. 2010;24(1):133-40.

70. Shim YK, Rachel JM, Ghia P, Boren J, Abbasi F, Dagklis A, et al. Monoclonal B-cell lymphocytosis in healthy blood donors: an unexpectedly common finding. Blood. 2014;123(9):1319-26. 